\title{
A systematic review of the psychological correlates of adjustment outcomes in adults with inflammatory bowel disease
}

Article

Accepted Version

Creative Commons: Attribution-Noncommercial-No Derivative Works 4.0

Jordan, C., Sin, J., Fear, N. T. and Chalder, T. (2016) A systematic review of the psychological correlates of adjustment outcomes in adults with inflammatory bowel disease. Clinical Psychology Review, 47. pp. 28-40. ISSN 0272-7358 doi: https://doi.org/10.1016/j.cpr.2016.06.001 Available at https://centaur.reading.ac.uk/71145/

It is advisable to refer to the publisher's version if you intend to cite from the work. See Guidance on citing.

To link to this article DOI: http://dx.doi.org/10.1016/j.cpr.2016.06.001

Publisher: Elsevier

All outputs in CentAUR are protected by Intellectual Property Rights law, including copyright law. Copyright and IPR is retained by the creators or other copyright holders. Terms and conditions for use of this material are defined in the End User Agreement.

www.reading.ac.uk/centaur 
Central Archive at the University of Reading

Reading's research outputs online 
A systematic review of the psychological correlates of adjustment outcomes in adults with inflammatory bowel disease.

Cheryl Jordan a, Jacqueline Sin b, Nicola T Fear b, Trudie Chalder b.

a, Faculty of Nursing and Midwifery, Kings College London, 57 Waterloo Road, London SE1 8WA. 02078483285

b, Department of Psychological Medicine, King's College London, Weston Education Centre, Cutcombe Road, London SE5 9RJ. 


\begin{abstract}
Inflammatory bowel disease (IBD) is a chronic long term condition which poses significant psychosocial adjustment challenges. The purpose of this review was to systematically identify psychological factors related to adjustment in adults with IBD with the aim of suggesting evidence based targets that may be modifiable though psychological intervention. Twenty five studies met inclusion criteria and were included in the systematic review and a narrative synthesis was conducted. A wide range of psychological variables were addressed covering six broad categories; personality traits, interpersonal traits, stress and coping, emotions and emotional control, IBD related cognitions and non IBD related cognitions. The most consistent relationship was found between certain emotion focused coping strategies and worse adjustment outcomes in IBD. Some evidence also hi-lighted a relationship between personality traits (such as neuroticism,) perceived stress, emotions and emotional control (such as alexithymia) and IBD related cognitions (such as illness perceptions) and negative adjustment outcomes. The results of this review suggest that interventions to improve adjustment in IBD may benefit from a focus on coping strategies, perceived stress and IBD related cognitions.
\end{abstract}

\title{
Introduction
}

The two main types of inflammatory bowel disease (IBD) are Crohn's disease (CD) and ulcerative colitis (UC). Both of these conditions affect men and women equally, with diagnosis usually occurring between the ages of 10 and 40 . The incidence and prevalence of IBD is increasing worldwide. The highest reported prevalence values for IBD are in Europe (UC, 505 per 100,000 persons; CD, 322 per 100,000 persons) and North America (UC, 249 per 100,000 persons; CD, 319 per 100,000 persons) (Molodecky et al, 2012). In Crohn's disease any part of the intestines can become intermittently inflamed, whereas in ulcerative colitis this is usually restricted to the colon. This produces a range of unpleasant and disabling symptoms including diarrhoea, fatigue, weight loss and pain in the abdomen. The course of IBD is idiosyncratic and unpredictable. Its exact aetiology is unknown and there is currently no certain cure. The current standard of care in IBD treatment is aimed at managing the inflammatory response during flare episodes and maintaining remission with an emphasis on adhering to a regular medication regime. In severe cases surgery may be required to remove part of or the entire large bowel, usually resulting in an ileostomy 
(Kiebles et al, 2010).

IBD poses numerous challenges for both physical and psychosocial functioning. Adults with IBD experience unpleasant and unpredictable symptoms and aggressive treatment regimes. In addition they face psychosocial consequences including disruptions to their life goals, employment, and social and leisure activities (Kemp et al 2012). Psychosocial difficulties are common in IBD when compared to both non-clinical (Kovac et al, 2007) and other chronic disease populations (Fillpovic et al, 2007). The empirical evidence demonstrates the life time prevalence rates of anxiety and depression to be as high as $35.8 \%$ (Walker et al, 2008). The presence of mood disturbance has also been established as being a risk factor for earlier and more active disease (Mittermaier et al, 2004, Graff et al, 2006).

Psychosocial adjustment in adults with IBD can be influenced by disease and socio demographic factors such as remission status, pain severity, relapses per year, treatment, extra intestinal manifestations and gender (Petrak et al, 2001, Goodhand et al, 2012, Moreno-Jimenez et al, 2007). However, these factors are variably associated with adjustment and are often only moderate predictors (Mussell et al, 2004, Turnball et al, 1995). Research demonstrates that psychological factors are often better predictors of individual differences in adjustment and in contrast to clinical or disease factors are potentially adaptable through psychological interventions (Kiebles et al, 2010 Mussell et al, 2004, Moreno-Jimenez et al, 2007, Dorrian et al, 2009).

A meta-analysis conducted by Timmer and colleagues (2011) concluded that there was no evidence that psychological interventions in general enhance emotional states, HRQOL and disease activity for adults with IBD. However, there are limitations to this review. The authors combined stress management, psychodynamic psychotherapy and cognitive behaviour therapy (CBT) studies as "psychotherapy" in the meta-analysis, therefore any differential efficacy between these theoretically distinct approaches could not be evaluated. When considered independently, a more recent review found promising evidence that CBT improved mental health in patients with IBD, both immediately following the intervention and at 6 months follow up (Knowles et al, 2013). 
In addition both reviews have included studies where the majority of participants have sub clinical levels of anxiety and depression which is likely to have reduced treatment effects. There is also a lack of information given about which psychological factors were targeted within interventions and how these factors were related to adjustment outcomes. Further work identifying the psychological factors that influence adjustment outcomes is warranted in order to identify sub groups of patients most likely to benefit from targeted psychological therapy (Timmer et al, 2011).

The purpose of this current review is to systematically review existing literature which addresses psychological factors that may be associated with, predict or explain adjustment outcomes in adults with IBD. The aims are to: a) Identify what types of psychological factors have been studied to date; b) Establish which psychological variables might serve to explain or predict differences in how well people adjust to living with IBD; c) Gain an overview of the strength of evidence for relationships between psychological variables and adjustment outcomes in IBD; d) Identify common methodological weaknesses in the research, gaps within the literature, and directions for future research.

For the purposes of this review it was necessary to make a conceptual distinction between factors potentially involved in predicting or explaining positive or negative adjustment outcomes and the outcomes themselves. Thus, within this review the term psychological factors is used to conceptualize potentially modifiable factors relating to an individual's beliefs, attitudes, perceptions, thoughts and behaviours that it would be possible to address in a psychological intervention. Although personality traits such as neuroticism and interpersonal attachment style are not usually considered modifiable targets for psychological intervention, the effect of these characteristics on cognitions and behaviour often are. These factors are therefore included in this review. The term adjustment outcomes pertains to indicators of positive or negative psychosocial adjustment such as psychological or emotional wellbeing, social and role functioning, quality of life (QOL) and self- reported perceptions of health and well-being. A reliable overview of this field will allow clinicians involved in delivering psychological interventions to increase their understanding of the factors linked to adjustment in IBD, so that these could be targeted in interventions. 
Although there have been review papers which have summarised the psychosocial issues associated with IBD (e.g., Sajadinejad et al 2012, Triantafillidis et al 2013, Sainsbury et al, 2006), these have not been systematic, a systematic review of this research is, therefore, timely.

\section{Method}

\section{Search strategy and selection criteria}

A search strategy was registered with the International Prospective Register of systematic reviews (Prospero: ID CRD42014007435). The systematic review protocol and data extraction forms were designed in accordance with the preferred reporting items for systematic reviews and meta analyses (Moher et al, 2009). Electronic databases (Medline, Embase, Web of Science, Cinahl and psychinfo) were systematically searched for studies published from inception to May 2015, which examined psychological factors relating to adjustment outcomes in IBD. Search terms were customised to each database and involved combining key word searches for a list of adjustment terms (e.g. 'psychosocial adjustment, depression, quality of life), and terms such as 'determin\$', 'predict\$, correlat\$, 'correlat\$, and the term 'Inflammatory bowel disease' 'Crohn's disease' and 'ulcerative colitis'.

\section{Inclusion and exclusion criteria}

Studies were included if they met the following criteria: (1) Published empirical quantitative research reports that examined relationships between psychological factors and adjustment outcomes in people over the age of 18 years with IBD; (2) Reported results for IBD participants separately from other conditions.

Studies were excluded if they (1) used qualitative, case report, expert opinion or consensus statement; (2) did not use published or appropriate and replicable multi- item measures to assess both psychological factors and adjustment outcomes; (3) did not examine the relationship between psychological factors and adjustment outcomes for people with IBD. Uncertainties concerning whether a study met inclusion criteria were resolved through discussion between the authors. 


\section{Data Extraction}

The database searches and study selection were undertaken by two people. The titles and abstracts were reviewed by one author (CJ). To enhance rigour $10 \%$ of all titles discounted at this stage and chosen at random, were independently reviewed by a second author (JS), and agreement was reached in all cases. The full texts were then screened by $\mathrm{CJ}$ and all ineligible papers excluded. Information relevant to the research question was systematically extracted and tabulated in order to aid comparison and synthesis of the studies. Extracted data comprised publication data, country of origin, study design and data analysis methodology, sample characteristics, relevant measures, main findings and aspects of methodological quality. The extraction process was completed independently by two of the authors, $\mathrm{CJ}$ and JS, and any disagreements resolved through discussion of the study with TC. Where only abstracts were available, or insufficient information was reported, authors were contacted via email. Only one paper was excluded due to insufficient information being reported and the author remaining un-contactable (fig 1).

\section{Data Synthesis}

The broad and multifaceted nature of the research question and the heterogeneity of the included studies precluded meta-analysis. Therefore, a narrative synthesis was conducted guided by the methods described by the Centre of Review and Dissemination, 2009. Psychological factors influencing adjustment were grouped into conceptually and thematically related constructs (e.g. illness perceptions, coping strategies).

Elements of study quality were also assessed. A quality scoring methodology was devised based on a quality assessment tool which was applicable for both cross sectional and longitudinal designs. This had been used in a previously published systematic review of psychological correlates of Rheumatoid Arthritis (Matcham et al, 2015). The quality score out of 7 was calculated based on the following criteria: whether the psychological factor was measured using a validated tool; Yes (score 1) No (score 0); Whether the adjustment outcome were measured using a validated tool; Yes (score 1) No (score 0); whether the recruitment strategy was random or consecutive; Yes (score 1) No (score 0); whether participants were recruited from multiple centres (representing multiple locations not just multiple centres within the same city, for example); Yes (score 1) No (score 0); whether eligibility criteria were 
specified; Yes (score 1) No (score 0); whether participation rate was greater than 75\%; Yes (score 1) No (score 0); whether the study reported it was adequately powered; Yes (score 1) No (score 0 ). Where studies did not report anything for a particular eligibility indicator, they were allocated to the no category. Final quality scores, together with the information used in their calculation, are shown in table 1.

\section{Results of the systematic search and overview of the included studies}

The literature search yielded 658 relevant articles (fig.1). Removal of duplicates, title and abstract screening left 39 for full text screening. Fourteen of these did not meet our eligibility criteria. The most common reason for exclusion was not examining the relationship between psychological factors and adjustment outcomes for adults with IBD. Twenty five studies were deemed eligible for inclusion in the narrative synthesis.

Table 1 presents the 25 studies included in the review. All but one study was cross sectional in design ( $\mathrm{N}=24)$. Self-report questionnaires were utilised for all the psychological factors and adjustment outcomes. Results were typically correlations or regression analyses. The majority of sample sizes were between 50 and 150. However three had less than 50 (Crane et al 2004, Turnball et al, 1995, Keibles et al, 2010) and one more than 1000 (Petrak et al, 2001). Generally samples included more women than men. The mean age of participants typically fell between 35 and 45 .

In all studies participants had a diagnosis of IBD which had been assessed by a gastroenterologist. Fourteen studies reported mean time since diagnosis for their sample. The majority used samples where the patients had been diagnosed on average between 5 and 10 years previously $(\mathrm{N}=12)$. A few samples had a mean diagnosis of less than 5 years.

Twelve studies reported mean levels of disease activity. The majority identified that between $30-40 \%$ of their sample was experiencing active symptoms at the time of the study $(\mathrm{N}=10)$. A few found less than $20 \%$ of their sample as having active symptoms. Only one study assessed the level of disease activity objectively through endoscopy and faecal calprotectin analysis (Goodhand et al, 2012). All other studies reported disease activity based on self- report symptom scores. In addition, three studies reported the amount of 
relapses participants had in the past year (Moreno-Jiménez et al, 2007, Boye et al, 2008, Inglesias et al, 2012).The most frequent setting for patient recruitment was outpatient clinics.

The included studies examined a range of adjustment outcomes. Quality of life (QOL) was the most common outcome of interest, however depression, anxiety, psychological distress and perceptions of disability were also studied. Only three studies reported findings separately for ulcerative colitis and Crohn's disease (Boye et al, 2008, Goodhand et al, 2012, Tabibian et al, 2015). All other studies, on finding no significant differences performed their statistical analysis on the group as a whole.

\section{Identified psychological variable}

A summary of the psychological variables identified and total sample size examining each variable is shown in table 2 . In total 18 different psychological variables were examined, which were categorised into six broad categories. Personality traits and interpersonal traits, stress and coping, emotion and emotional processing, IBD related cognitions and non IBD related cognitions.

The remainder of the results section summarises and synthesises findings regarding the relationships between psychological factors (grouped into thematically or conceptuallyrelated categories) and adjustment outcomes.

\section{Personality traits}

A key theme in the adjustment literature is the importance of personality factors in mediating the psychosocial impact of chronic physical illness. Over the last decade several studies have investigated the influence of personality variables such as neuroticism and perfectionism on adjustment outcomes in IBD. Each of these constructs is hypothesised to play a role in psychosocial wellbeing through its impact on the way an individual reacts to the diagnosis of IBD, its symptoms or other stressful events. Neuroticism, for example is characterised by emotional instability and a tendency to interpret situations as threatening. Individuals who score high for neuroticism may, therefore, be predisposed to making extreme attributions in relation to their IBD and its symptoms and experiencing intense 
emotional reactions as a result (Eysenck et al, 1976). Perfectionists tend to strive relentlessly towards unobtainable goals, valuing their self-worth in terms of productivity and accomplishments. Individuals high in this trait may therefore be more prone to evaluating themselves negatively in-light of the disruption caused by IBD to their life goals (Flett et al, 2002).

Five studies have investigated the link between three personality traits and adjustment outcomes; neuroticism, perfectionism and type D personality (Flett et al, 2011, Boye et al, 2008, Moreno-Jiménez et al 2007 Liu et al, 2013, Sajadinejad et al, 2012) (table 2). At a cross sectional bivariate level, preliminary evidence (1/1) suggests a significant relationship between other $(r=.50 p<0.001)$, and socially prescribed $(r=.59 p<0.001)$ perfectionism and reduced psychosocial functioning. Whether this relationship would be sustained at a multivariate level is yet to be tested (Flett et al, 2011).This study has a high quality score of 5 (table 1).

At a multivariable level after adjusting for socio demographic and clinical factors, $100 \%$ of results (4/4) show neuroticism (Boye et al, 2008, Moreno-Jiménez et al 2007 Liu et al, 2013, Sajadinejad et al, 2012) and type D personality (1/1) ( $\beta-0.053 p<0.001$ Sajadinejad et al, 2012), to be significantly associated with a reduced quality of life. Further, neuroticism was specifically associated with worse emotional and social functioning, and with reduced vitality (Boye et al, 2008, Moreno-Jiménez et al 2007). These studies have quality scores of between 3-4 (table 1).

The strength of association between neuroticism $(\mathrm{p}<0.001)$ and QOL was largely consistent and equal to clinical variables $(P<0.001)$ across the five studies. Even those studies with small sample sizes found strong associations between neuroticism and QOL (e.g. $N=58 \beta$ $.49 \mathrm{P}<0.001$, Sajadinejad et al, 2012). The unique variance explained by neuroticism was not given in any of these studies.

\section{Interpersonal traits}

Two studies examined the role of attachment style on adjustment outcomes in IBD. Attachment style is a psychological concept that attempts to describe the dynamics of 
interpersonal relationships between humans. It addresses how individuals respond within relationships when hurt or perceiving a threat. It is conceptualized as secure or insecure, in the form of avoidant or anxious-ambivalent attachment (Waters et al, 2005). At a multivariate level, after controlling for age and recruitment phase, greater anxious attachment ( $\beta=0.29, P=0.002$ ) was significantly associated with worse QOL (Caplan et al, 2014). Attachment avoidance and attachment anxiety also showed significant bivariate associations with depression at baseline and follow up in one longitudinal study (Maunder et al, 2005). However these studies have a low quality score of 2 and 3 respectively.

\section{Stress and coping}

Psychological stress has long been reported anecdotally to increase symptomatic disease activity in IBD. Recent empirical advances have provided some support for this and proposed that stress may increase gut motility and fluid secretion (Mawdsley et al, 2005). According to the stress coping model of Lazarus and Folkman (1984), a dominant paradigm in the field of psychosocial adjustment to chronic illness, the experience of stress in response to difficulties is influenced by the individual's evaluations and appraisals of the stressor and the coping strategies they use to manage it. The following section deals first with the appraisal aspect of the model and then the coping aspects.

\section{Perceptions of stress}

As this review is concerned with modifiable psychological factors, we did not examine studies that simply investigated the frequency of life events. Included studies which investigated stress had to judge the subjective, perceived degree of stress reported by the participant.

Four studies examined the role of perceived stress on adjustment outcomes, all cross sectional in design (Kiebles et al, 2010, Goodhand et al, 2012, Sewitch et al, 2001,Tabibian et al, 2015) (Table 4). At a multivariate level, $100 \%$ of results (4/4) found a statistically significant relationship between perceived stress and a reduced quality of life, $(p=0.01)$ increased psychological distress $(r=0.04 P=0.03)$, anxiety $(\beta 0.1 P<0.01)$ and depression $(\beta$ $0.15 \mathrm{P}<0.01)$. Significant covariates across the majority of studies included symptomatic disease activity $(r=0.10 P=0.02)$ and having a newer diagnosis $(r=-0.71 P=0.01)$. A further 
$50 \%$ of results $(2 / 4)$ found that being female $(p=0.0015)$ and older age $(\beta 0.05 P=0.001)$

were additional independent correlates of depression in CD (Goodhand et al, 2012, Tabibian et al, 2015). Examination of study quality (table 1) demonstrated that the small number of studies in this category were of low-moderate quality with scores between 3-4.

In addition, there was some preliminary evidence that the relationship between psychological distress and perceived stress changed depending on the level of satisfaction with social support $(r=-0.014 P=0.02)$.

\section{Coping}

Coping strategies refer to the specific efforts, both behavioural and psychological, that people employ to master, tolerate, reduce, or minimize stressful events (Folkman et al, 1991). Historically coping strategies have been measured and categorised in a multitude of ways, however most coping theories broadly classify coping attempts as either emotion focused or problem focused strategies (e.g. Lazarus et al 1985).

Ten studies considered the relationship between coping strategies and adjustment outcomes, all cross sectional in design (Table 2). At multivariate level after taking sociodemographic and disease variables into consideration, the results of five out of seven studies show a statistically significant relationship between emotion focused coping strategies and reduced quality of life, psychological distress, anxiety and depression (Mussell et al, 2004, Petrak et al, 2001, Smolen et al, 1993, Seres at al, 2008, Dorian et al, 2009).

There are some differences between studies in the reported amount of variance explained by coping strategies. The largest study in this category with a sample size of 1322 found that emotion focused coping explained $16 \%$ of the variance in QOL. In addition, diagnosis showed a significant influence on this outcome explaining 9\% of the variance (Petrak et al, 2001). The results of the majority of studies reported similar findings with emotion focused coping explaining a larger proportion of variance in adjustment outcomes than disease related or demographic characteristics. In contrast, in a series of hierarchical regression models coping did not significantly add to predicting adjustment once illness perceptions 
were controlled for ( $3 \%$ of the variance in psychological distress) ( Dorrian et al, 2009). One possible explanation for this weaker association may be the choice of a generic list of coping strategies to assess coping with IBD. The COPE is designed for use in a variety of situations and may omit some important disease-specific coping strategies. A coping list tailored to the specific tasks associated with IBD may be more appropriate and may produce different results (Dorrian et al, 2009). These studies were all of moderate to high quality with scores ranging between 4-5.

No statistically significant relationships between coping, disease type, age of onset, gender, symptomatic disease activity, and quality of life were found in 2 studies with quality scores of 2-3 (Turnball et al, 1995, Faust et al, 2012).

In contrast, the more adaptive emotion focused strategy of optimistic coping e.g. thinking positively, related to a better quality of life $(\beta 11.7 \mathrm{P}=0.01)$ in one study (Smolen et al, 1993). Further, problem focused coping was linked to a reduced quality of life. However, this relationship was solely apparent during an active phase of the disease $(\beta 0.02 \mathrm{P}<0.00)$ (Petrak et al, 2001).

\section{Emotion and emotional control}

Psychological variables examining aspects of emotions or emotional processing were allocated to this group. These variables include hostile feelings and expressed aggression, emotional control, alexithymia and private self- consciousness. Eight studies examined the associations between these variables and quality of life, all using a cross sectional design.

At a multivariate level, results showed that both alexithymia and private self-consciousness were significantly associated with negative adjustment outcomes. Four studies (4/4), found a significant relationship between alexithymia and reduced social, physical and emotional functioning on both generic and IBD specific measures of quality of life (Moreno-Jiménez et al, 2007, Boye et al, 2008, Iglesias-Rey et al, 2012, Verissimo et al, 1998). The strength of association between alexithymia and QOL was largely consistent across studies with $p$ values ranging from $<0.01$ to 0.001 . In addition Verissimo et al, 1998, performed a hierarchical, stepwise multiple regression analysis and found that alexithymia scores 
accounted for an additional $12.4 \%$ of the variance in predicting quality of life after controlling for socio demographic and disease related factors. The majority of results found this trend with educational levels, gender, socioeconomic index, extra-intestinal manifestations, current symptomatic disease activity and number of relapses per year being additional independent correlates of negative adjustment outcomes. These studies each have a quality score of 4 .

Only one study of poor quality considered the relationship between private selfconsciousness and quality of life. The findings suggested a heightened awareness of inner thoughts and feelings was associated with worse QOL, with symptomatic disease activity being a further significant covariate (Olbrisch et al, 1982).

Mixed evidence was found for the role of expressed aggression and hostile feelings in determining adjustment in IBD. Previous research has linked this trait to higher levels of subjective illness, poor health habits and interpersonal conflicts, which may reduce overall quality of life (Boye et al, 2008). At a multivariate level, Boye et al 2008, found expressed aggression and hostility to be significantly associated with reduced generic quality of life in Crohn's disease only ( $\beta-1.5 \quad p<0.02$ Boye et al, 2008). This study had a quality rating of 4 . Another study of poor quality (Lui et al, 2013) found no significant relationships between this variable and adjustment outcomes. Symptomatic disease activity was a significant covariate of negative adjustment outcomes in both studies.

In contrast, one study found having higher active control of emotions to be significantly linked to a better quality of life (Verissimo et al, 1998). Emotional control scores ( $\beta=0.261$ ) contributed an additional $5.6 \%$ of the variance over and beyond the contributions of education $(B=-0.073)$, socioeconomic index $(B=-0.094)$, and alexithymia $(B=-0.277)(R 2=$ $0.206 ; F[4,57]=3.69, p<0.01$ ) (Verissimo et al, 1998). This study has a quality score of 3 .

\section{IBD related cognitions}

Seven studies examined adjustment in relation to IBD cognitions. IBD cognitions relate to perceptions or thoughts related to IBD, which may be associated with negative adjustment outcomes. The common sense model of illness (leventhal et al, 1984) proposes that when 
faced with a health threat individuals construct their own representations or perceptions of their illness which then guide their ways of responding, and ultimately their adjustment. For example individuals will hold beliefs about responsibility for health outcomes. They may believe that either they, others or fate will shape the impact of their illness (Mussell et al, 2004). In addition, IBD cognitions can relate to concerns about the impact of the disease or being stigmatised or alienated due to the nature of IBD symptoms (Kiebles et al, 2010).

At a multivariate level, feeling stigmatised (1/1) unsupported and misunderstood (1/1) and believing that IBD will have serious consequences $(1 / 1)$ were significantly associated with negative adjustment outcomes after controlling for illness severity and demographic variables. Current evidence suggests that perceived stigma accounts for $10 \%-22 \%$ of the variance in health-related quality of life scores, $4 \%-16 \%$ for psychological distress, and $15 \%$ of the variance in anxiety and depression (Taft et al, 2009). This study has a quality score of 3. Similar to stigma, perceiving oneself to be misunderstood or alienated from one's social support network when seeking support was significantly associated with reduced quality of life $(t-2.23 p=<0.05)$ (Faust et al, 2012). Further preliminary evidence suggests that believing that IBD will have serious consequences explains a greater proportion of variance in psychological distress than demographic or clinical factors (32\% as opposed to $23 \%$ ) (Dorrian et al, 2007).This study has a quality score of 5 , one of the highest of any study included in this review.

Conflicting evidence exists for the influence of locus of control on adjustment outcomes in IBD at a multivariate level (Boye et al, 2008, Mussell et al 2004). Only one study found internal locus of control to be significantly associated with a better of quality of life. Whilst a powerful other tendency and chance locus of control was linked to a reduced quality of life (Boye et al, 2008). Quality scores for these studies ranged between 4-5.

At a bivariate level, symptom tolerance and activity engagement have been linked to better adjustment outcomes (kiebles et al, 2010). Whether this relationship would be sustained in multivariate analysis is yet to be tested. Patient's knowledge, skill, and confidence in selfhealth management has also shown links to positive adjustment outcomes. However the population was comprised entirely of veterans, predominantly older and male, who 
received care in a limited geographical region (Kentucky and Tennessee, USA), thus these conclusions may not apply to other clinical IBD populations (Munson et al 2009). These studies had quality scores of 3 ( kiebels et al 2010) and 4 (Munsun et al, 2009).

\section{Non IBD related cognitions}

Two studies examined adjustment in relation to non IBD related cognitions. Non IBD cognitions pertain to global perceptions or thoughts which are not focused on the experience of having IBD such as global self- esteem and general hopelessness which may be associated with adjustment outcomes.

At a multivariate level both self- esteem and hopelessness are significantly associated with quality of life, albeit in different ways. Self- esteem was most strongly associated with positive social functioning on a health related quality of life measure $(\beta .35 \mathrm{P}=<0.001)$. Associations were also found between this predictor variable and better perceptions of systemic ( $\beta 0.20 \mathrm{P}=<0.05)$ and emotional functioning $(\beta .28 \mathrm{P}=<0.01)$ (Moreno-Jiménez et al 2007). This study has a quality score of 4 . In contrast, hopelessness was found to be negatively associated with the mental subscale of health related quality of life explaining $4.9 \%$ of the variance found in this outcome (Petrak et al, 2001).This study has a quality score of 5 .

\section{Discussion}

Summary of main findings

The aim of this review was to identify studies of psychological variables and their associations with adjustment outcomes in adults with IBD. A systematic search of the literature identified several psychological correlates of adjustment which were grouped into six categories; personality traits, interpersonal traits, stress and coping, emotions and emotional control, IBD related cognitions and non IBD related cognitions.

The most studied personality trait is neuroticism. Consistently at a multivariate level results show neuroticism to be significantly associated with negative adjustment outcomes, specifically with reduced emotional functioning (Boye et al, 2008, Moreno-Jiménez et al 
2007 Liu et al, 2013, Sajadinejad et al, 2012).Neuroticism shows an equal influence on adjustment outcomes as clinical variables such as relapses per year and type of treatment. Preliminary evidence suggests that Type $D$ personality may have a similar influence on outcomes (Liu et al, 2013). Perfectionism is also unhelpful for adjustment, however whether this relationship would be maintained when taking socio-demographic and disease variables into consideration is currently unknown but warrants further investigation (Flett et al, 2011). Personality variables are likely to be important in understanding the psychological factors that predispose an individual to developing unhelpful cognitive and behavioural responses to IBD.

Attachment style has also been identified as influencing adjustment to IBD (Maunder et al, 2005, Caplan et al, 2014) with links to depression and a reduced quality of life.

Understanding insecure attachment in the context of relationships with health care staff may be useful in promoting, developing and sustaining supportive relationships.

Perceptions of being under stress consistently links to negative adjustment outcomes, demonstrating a similar influence to sociodemographic and disease related factors (Kiebles et al, 2010, Goodhand et al, 2012, Sewitch et al, 2001,Tabibian et al, 2015). Interestingly there is some preliminary evidence that social support mitigates the impact stress has on a person's mental health. Understanding obstacles to engaging in social relationships such having an insecure attachment style may therefore be important in promoting supportive social relationships and ultimately positive adjustment.

Consistently the evidence suggests a significant association between emotion focused coping methods and a reduced quality of life and increased psychological distress at a multivariate level (Cranes et al, 2003, Kiebles et al, 2010, Mussell et al, 2004, Petrak et al, 2001, Smolen et al, 1993, Seres at al, 2008, Dorian et al, 2009, Seres et al 2008, Turnball et al, 1995, Faust et al 2012).

When considering emotions and emotional control, several studies found an association between alexithymia and a reduced quality of life which is significant at a multivariate level (Moreno-Jiménez et al, 2007, Boye et al, 2008, Iglesias-Rey et al, 2012, Verissimo et al, 
1998). Alexithymia is defined as a difficulty in identifying and describing emotions which can lead to greater avoidant behaviours and fewer intimate relationships, both of which are likely to be unhelpful for quality of life (Inglesias-Rey et al, 2012). Contradictory evidence exists for a link between aggression and hostility and quality of life with one finding a relationship (Boye et al, 2008) and one not (Lui et al, 2013). Further, at a multivariate level a heightened awareness of inner thoughts and feelings was linked to a reduced quality of life in one study (Olbrisch et al, 1982), whilst scoring higher for emotional control was associated with improvements in this outcome in another (Verissimo et al, 1998). Clearly further studies are required to elucidate the nature of these relationships. It is possible that extreme emotional responses are unhelpful.

Current evidence suggests that several thoughts and perceptions concerning IBD link to unhelpful adjustment outcomes. At a multivariate level, feeling stigmatised (Taft et al, 2009), socially constrained (Faust et al, 2012), having an emotional representation of the illness and believing that it will have serious consequences (Dorrian et al, 2007) were all significantly associated with psychological distress and a reduced quality of life. In contrast feeling optimistic and confident in one's knowledge and skills to manage health linked to an increased quality of life score, albeit in a specific population of veterans (Munsun et al, 2009). At a bivariate level acceptance towards the symptoms and engagement with valued activities despite them was associated with better emotional and social functioning and reduced psychological distress (Kiebles et al, 2010). However each of these psychological variables has been investigated by only one study. Clearly research in this area is very much in its infancy but the findings suggest further exploration is warranted.

Non IBD related cognitions which appear to be important to adjustment are self- esteem which one study linked to better adjustment (Moreno-Jiménez et al 2007) and hopelessness which showed associations with poorer outcomes (Petrak et al, 2001).

Importantly, the results of our review suggest that even though socio-demographic and disease related factors such as lower socioeconomic status, gender and symptomatic disease activity play an important role in adjustment, psychological variables maintain their significance when controlling for the influence of these factors. Overall, psychological 
variables consistently link to worse mental health outcomes whether measured as psychological distress or emotional functioning as part of overall quality of life. However, all but one study was cross sectional in design without any element of follow up. The lack of any longitudinal data means that causal relationships between psychological factors and outcomes cannot be established and it is not possible to discern which factors are most important for adjustment in IBD.

\section{Psychological model of understanding adjustment in IBD.}

This review sought to systematically review and synthesise the evidence base for the psychological correlates of adjustment and consequently we propose a psychological model of understanding adjustment to IBD (fig 2). This is consistent with psychological models of adjustment in other chronic illnesses such as multiple sclerosis and rheumatoid arthritis (Dennison et al 2009, Matcham et al, 2015). The onset of increased psychological distress and a reduction in quality of life and functioning is likely to be associated with a trigger such as the onset of symptoms at the start of a flare episode of IBD. This disturbance in mood and quality of life might then be maintained over time by disease activity but also by cognitive and behavioural factors. Feeling misunderstood or judged because of the symptoms, might lead to a person feeling low in mood and employing emotion focused coping strategies such as behaviourally disengaging from social activities. The resulting isolation might then maintain or exacerbate the low mood. As depression has been identified as a risk factor for increased disease activity, this might create a vicious circle whereby disease activity leads to a set of thoughts and behaviours which trigger more disease activity and vice versa. Disease activity and psychosocial functioning are therefore likely to be interrelated and bidirectional. In contrast, acceptance and tolerance of symptoms and engaging in meaningful activities, feeling confident in skills and abilities to manage health and employing optimistic coping strategies may help a person to manage or appraise their symptoms of IBD more effectively.

\section{Strengths and limitations}

A strength of this review is that it was conducted using a rigorous and replicable methodology with abstract screening and data extraction being carried out by independent researchers in order to minimise bias. However, this review has some limitations. Only 
studies published in peer reviewed journals were considered. The choice of research questions to address in this review meant that a broad range of studies were included. This resulted in a vast variation both between and within psychological categories which precluded meta-analysis, it was, therefore, not possible to formally assess the extent of publication bias in a sensitivity analysis or funnel plot.

The quality of studies included varied but was generally low. All but one study was cross sectional in design. Therefore, there are limited conclusions which can be drawn as to the nature and direction of the relationship between psychological variables and adjustment outcomes.

A wide range of validated measures were used in the studies. Disease related factors (such as current symptoms, relapses in the past year) examined in this review were self-reported in all but one study. It is likely that objective measurements of disease activity through endoscopy and faecal calprotectin analysis give a more robust indication of disease activity as distress may act as a confounder and could potentially lead to inflated reporting of this phenomenon.

Most studies used appropriate statistical methods for analysing data and accounted for the presence of confounding variables during the analysis. Sample size calculations were absent from all but one of the studies included in this review and most studies had small sample sizes. Small samples could render studies underpowered to detect relationships or mean that positive findings might not generalise to larger or different populations. The majority of studies described demographic sample characteristics such as age, gender and time since diagnosis, although many did not specify details such as socioeconomic status or ethnicity making it difficult in some instances to assess the representativeness of these samples.

All of the studies reported a recruitment strategy. Five studies used consecutive sampling, whilst the rest employed a convenience sample mostly from outpatient clinics although a few additionally recruited through patient organisations. An advantage of this type of sampling is that is less open to selection bias because the participants are likely to be less selected than in randomised controlled trials. In addition, all but three studies stated their 
inclusion/exclusion criteria (Table 1). On review, selection bias was potentially present in two studies whose sample or part of, was recruited primarily to participate in stress reduction intervention studies.

A further consideration is the limited number of studies in this area and narrow range of psychological variables that have been examined. The findings of a recent Meta synthesis of qualitative studies identified fear of embarrassing symptoms occurring in public and avoidance and isolation which results from this as a major theme in the experience of living with IBD (Kemp et al, 2012). Currently no studies have utilised measures that might capture this or have examined the links between this and adjustment outcomes. Our conclusions relating to psychological factors and adjustment are, therefore, limited by a small quantity of studies focused on a limited range of psychological variables, not all of which are congruent with the experience of people with IBD as identified in the qualitative literature.

\section{Clinical implications of key findings}

The findings of this review may have clinical implications. For example, although increased psychological distress and reduced quality of life are commonly reported in IBD patients and has been linked to worse outcomes, it is not consistently measured as an outcome in clinical practice. It may be preferable to include measures of psychosocial adjustment as a routine outcome variable because of its relevance to patients, link to increased disease activity and potential for treatment. Mood and quality of life can be assessed when patients first present to health services and then monitored throughout the course of treatment. Early identification and management could prevent disturbances in mood and quality of life from negatively influencing outcomes for people with IBD.

The results of this review suggest that adjustment is correlated with several psychological factors that could be amenable to change. The application of cognitive behavioural approaches could help identify any unhelpful interactions between symptoms and cognitive and behavioural responses. By using strategies such as testing out thoughts and appraisals about symptoms, a patient might be encouraged to share their experience with a close friend to test the accuracy of their perception that no one will understand. This could lead to an increase in social contact and improve low mood, which may serve to decrease 
disease activity. Preliminary evidence from a recent randomised controlled trial suggests that CBT can be useful in improving the quality of life of participants with IBD and poor mental health at 6 months (Mikocka et al, 2015).

Acceptance and tolerance of symptoms and engaging in meaningful activities has been linked to positive adjustment in IBD. The development of this type of psychological flexibility could be encouraged through the application of acceptance and commitment therapy ( $A C T$ ), which has recently emerged as a third wave within the field of CBT. ACT emphasizes observing thoughts and feelings as they are, without trying to change them, and behaving in ways consistent with valued goals and life directions. This approach has shown some promising results in improving outcomes for people with chronic pain but is yet to be examined in the context of IBD (Davis et al, 2015).

A benefit of CBT approaches is that they can be delivered in a variety of ways. Staff at IBD clinics could be trained to deliver low intensity interventions such as working through CBT based self-help manuals with patients. For more severe problems in adjustment high intensity 1:1 CBT may be indicated. Pharmacological treatment of emotional symptoms may also be beneficial in improving outcomes in IBD.

\section{Recommendations for future research}

Based on the quality assessment of studies included in this review, we can make some suggestions for future studies of psychological correlates of adjustment in IBD.

Studies should have a prospective design so that causal associations and mediators can be examined. The sample size should be large enough for a well powered statistical analysis and to account for attrition during the course of the study. In order to reduce selection bias and increase generalisability participants should be recruited consecutively from primary or secondary care and from multiple centres.

A model of understanding adjustment in IBD should be based on previous theory and evidence taking into account the findings of qualitative studies focused on living with IBD. New research should expand the range of social, cognitive and behavioural factors 
examined in relation to adjustment over time and the choice of measures should be guided by this model. In addition, disease activity should be measured objectively through endoscopy and faecal calprotectin analysis and subjectively via self -report measures. The associations between these bio-psycho-social factors and adjustment can then be examined in multivariate analysis.

\section{Conclusions}

This review has shown that adjustment to IBD is associated with a number of psychological and disease related factors. These relationships have been illustrated in the form of a psychological model of understanding adjustment to IBD. Longitudinal studies are needed in order to understand the nature of adjustment in IBD and any causal relationships with psychosocial factors. The range of psychological factors examined in studies should be expanded to incorporate the themes identified as representing the experience of living with IBD as identified in qualitative studies. Individuals with IBD are likely to benefit from psychological and pharmacological interventions which target these factors.

\section{References}

Addolorato, G., Capristo, E., Stefanini, G.F., Gasbarrini, G., (1997). Inflammatory bowel disease: a study of the association between anxiety and depression, physical morbidity, and nutritional status. Scandinavian Journal of Gastroenterology, 32 (10), pp. 1013-1021.

Boye, B. K. E. A., Lundin, S., Leganger, K., Mokleby, G., Jantschek, I., Jantschek, S., Kunzendorf, D., Benninghoven, M., Sharpe, I,. Wilhelmsen, S., Blomhoff, U. F., Jahnsen, M.J., (2008). The INSPIRE study: Do personality traits predict general quality of life (short form-36) in distressed patients with ulcerative colitis and Crohn's disease?. Scandinavian Journal of Gastroenterology 43(12), pp. 1505-1513.

Caplan, R.A., Maunder, R.G., Stempak, J.M., Silverberg, M.S., Hart, T.L. (2014). Attachment, Childhood Abuse, and IBD-related Quality of Life and Disease Activity Outcomes.

Inflammatory Bowel Disease. 20(5), pp. 909-915.

Centre for reviews and dissemination, (2009). CRD's guidance for undertaking reviews in health care. University of York.

Crane, C., Martin, M. (2004). Social learning, affective state and passive coping in irritable bowel syndrome and inflammatory bowel disease. General Hospital Psychiatry 26(1), pp. 50-58. 
Davis, M. L., Morina, N., Powers, M. B., Smits, J. A. J., Emmelkamp, P. M. G. (2015). A MetaAnalysis of the Efficacy of Acceptance and Commitment Therapy for Clinically Relevant Mental and Physical Health Problems. Psychotherapy and Psychosomatics 84 (1), pp. 30-36.

Dennison L.,Moss-Morris, R., Chalder, T.(2009).A review of the psychological correlates of adjustment in patients with multiple sclerosis .Clinical Psychology Review 29, pp 141-153.

Dorrian, A., Dempster M., Adair A.(2009). "Adjustment to inflammatory bowel disease: The relative influence of illness perceptions and coping." Inflammatory Bowel Diseases 15(1),pp 47-55.

Eysenck, H. J., Eysenck, S.B.G., (1976). Psychoticism as a Dimension of Personality. London, Hodder \& Stoughton.

Faust, A. H., Halpern,L.F., Danoff-Burg, S., Cross, R.K., (2012). Psychosocial factors contributing to inflammatory bowel disease activity and health-related quality of life. Gastroenterology and Hepatology 8(3), pp 173-181.

Filipović B R, Filipović B F, Kerkez M, Milinić N, Randelović T., (2007).Depression and anxiety levels in therapy-naive patients with inflammatory bowel disease and cancer of the colon. World J Gastroenterology. 13(3), pp 438-43.

Flett, G. L., Baricza, C., Gupta, A., Hewitt P.L., Endler, N.S., (2011).Perfectionism, psychosocial impact and coping with irritable bowel disease: A study of patients with Crohn's disease and ulcerative colitis. Journal of Health Psychology 16(4), pp 561-571.

Goodhand, J. R., Wahed, M., Mawdsley, J.E., Farmer, A.D., Aziz, Q., Rampton, D.S., (2012). Mood disorders in inflammatory bowel disease: relation to diagnosis, disease activity, perceived stress, and other factors. Inflammatory Bowel Diseases 18(12), pp 2301-2309.

Graff, L. A., Walker, J., Lix, R., Clara, L., Rawsthorne, I., Rogala, P., Miller, L., Jakul, N., McPhail, L., Ediger, C., Bernstein, J. (2006). The Relationship of Inflammatory Bowel Disease Type and Activity to Psychological Functioning and Quality of Life. Clinical Gastroenterology and Hepatology 4 (12), pp1491-1501.

Green, B.F., Hall, J. A.(1984)." Quantitative methods for literature reviews. Annual review of psychology, 35,pp 37-53.

Iglesias-Rey, M., Barreiro-De Acosta, M., Caamano-Isorna, F., Vazquez Rodriguez, I., Lorenzo Gonzalez, A., Bello-Paderne, X., Dominguez-Munoz, J.E., (2012). Influence of alexithymia on health-related quality of life in inflammatory bowel disease: Are there any related factors?. Scandinavian Journal of Gastroenterology 47(4), pp 445-453.

Kemp K, Griffiths J, Lovell, K., (2012). Understanding the health and social care needs of people living with IBD: a meta-synthesis of the evidence. World J gastroenterol. 18(43), pp6240-6249.

Kiebles, J. L., Doerfler, B.,Keefer, L., (2010). Preliminary evidence supporting a framework of psychological adjustment to inflammatory bowel disease. Inflammatory Bowel Diseases 
16(10), pp 1685-1695.

Kinash R.G., Fischer D.G., Lukie B.E., (1993). Coping patterns and related characteristics in patients with inflammatory bowel disease. Rehab Nurs.18, pp 12-19.

Knowles, S., Monshat, K., Castle, D.,2013. The Efficacy and Methodological Challenges of Psychotherapy for Adults with Inflammatory Bowel Disease: A Review. Inflammatory Bowel Diseases,19(12) pp2704-2715.

Kovacs, Z., Seres, G., Kerekgyarto, O., Czobor, P.(2010). Psychopathological Symptom Dimensions in Patients with Gastrointestinal Disorders. Journal of Clinical Psychology in Medical Settings. 17(4), pp 378-386.

Lazurus, R.S., Folkman, S. (1984).Stress, appraisal and coping. New York. Springer.

Liu, S., Ren, J., 1 Hong, Z., Li, X., Yao, M., Yan, D., Ren, H., Wu, X., Wang, G., Gu, G., Xia, Q., Han, G., Li, J., (2013). An Evil Backstage Manipulator: Psychological Factors Correlated with Health-Related Quality of Life in Chinese Patients with Crohn's Disease. The Scientific World Journal. Volume 2013, pp 1-9.

Matcham F., Ali, S., Hotopf, M., Chalder, T. (2015).Psychological correlates of fatigue in rheumatoid arthritis: A systematic review. Clinical psychology review 39, pp 16-29.

Maunder, R.G., Lancee, W.J., Hunter, J.J., Greenberg, G.R., Steinhart, H.A., (2005). Attachment Insecurity Moderates the Relationship Between Disease Activity and Depressive Symptoms in Ulcerative Colitis. Inflamm Bowel Dis 11(10), pp 919-926.

Mawdsley, J. E., Rampton, D.S. (2005). "Psychological stress in IBD: new insights into pathogenic and therapeutic implications." Gut 54(10), pp 1481-1491.

Mikocka-Walus, A., Bampton, P., Hetzel, D., Hughes, P., Esterman, A., Andrews, J.M., (2015) Cognitive-behavioural therapy has no effect on disease activity but improves quality of life in subgroups of patients with inflammatory bowel disease: a pilot randomised controlled trial. BMC Gastroenterology.15(54), pp 1-12.

Mittermaier, C., Dejaco, C., Waldhoer, T., Oefferlauber-Ernst, A., Miehsler, W., Beier, M., Tillinger, W., Gangl, A., Moser, G. (2004). Impact of depressive mood on relapse in patients with inflammatory bowel disease: A prospective 18-month follow-up study. Psychosomatic Medicine 66(1), pp 79-84.

Moher, D., Liberati, A., Tetzlaff, J., Altman, D. G. the PRISMA group. (2009). The PRISMA group. Preferred reporting items for Systematic Reviews and Meta-analysis: The PRISMA statement. British Medical Journal, 339,(2535).

Molodecky NA ${ }^{1}$, Soon IS, Rabi DM, Ghali WA, Ferris M, Chernoff G, Benchimol El, Panaccione R, Ghosh S, Barkema HW, Kaplan GG, 2012. Increasing incidence and prevalence 
of the inflammatory bowel diseases with time, based on systematic review. Gastroenterology. 142(1) pp 46-54

Moreno-Jimenez, B., Lopez Blanco, B., Rodriguez-Munoz A., Garrosa Hernandez, E.(2007). The influence of personality factors on health-related quality of life of patients with inflammatory bowel disease. Journal of Psychosomatic Research 62(1), pp 39-46.

Munson, G. W., Wallston, K. A., Dittus, R. S., Speroff T., Roumie C. L. (2009). Activation and perceived expectancies: Correlations with health outcomes among veterans with inflammatory bowel disease. Journal of General Internal Medicine 24(7), pp 809-815.

Mussell, M., U. Bocker, U., Nagel, N., Singer, M. V. (2004). Predictors of disease-related concerns and other aspects of health-related quality of life in outpatients with inflammatory bowel disease. European Journal of Gastroenterology and Hepatology 16(12), pp 1273-1280.

National Association for Colitis and Crohn's Disease (NACC), 2003. Living with IBD. NACC. Hertfordshire.

Olbrisch, M. E., Ziegler, S. W. (1982).Psychological adjustment to inflammatory bowel disease: Informational control and private self-consciousness. Journal of Chronic Diseases 35(7), pp 573-580.

Petrak, F., J. Hardt, T., Clement, N., Borner, Egle, U. T., Hoffmann, S.O. (2001). Impaired health-related quality of life in inflammatory bowel diseases: psychosocial impact and coping styles in a national German sample. Scandinavian Journal of Gastroenterology 36(4), pp 375-382.

Sainsbury, A., Heatley, R.V. (2005). Review article: psychosocial factors in the quality of life of patients with inflammatory bowel disease. Alimentary Pharmacology and Therapeutics, 21 ( 5), pp. 499-508.

Sajadinejad, M. S., Molavi, H,. Asgari, K., Kalantari, M., Adibi, P. (2012). Personality dimensions and type $D$ personality in female patients with ulcerative colitis. Journal of Research in Medical Sciences 17(10), pp 898-904.

Sajadinejad, M. S., Asgari,K., Molavi, H., Kalantari, M., Adibi, P.(2012). Psychological Issues in Inflammatory Bowel Disease: An Overview," Gastroenterology Research and Practice, vol. 2012.

Seres, G., Kovacs, Z., Kovacs A., Kerekgyarto, O., Sardi, K., Demeter, P., Meszaros, E., Tury, F. (2008). Different Associations of Health Related Quality of Life with Pain, Psychological Distress and Coping Strategies in Patients with Irritable Bowel Syndrome and Inflammatory Bowel Disorder. Journal of Clinical Psychology in Medical Settings 15(4),pp 287-295.

Sewitch, M. J., Abrahamowicz, M., Bitton, A., Daly, D., Wild, G., E., Cohen, A., Katz, S., Szego, P.L., Dobkin, P. L. (2001). Psychological Distress, Social Support, and Disease Activity in 
Patients With Inflammatory Bowel Disease. The American journal of Gastroenterology 96(5). pp 1470-1479.

Smolen, D., TOPP, R.(1998). Coping Methods of Patients with Inflammatory Bowel Disease and Prediction of Perceived Health, Functional Status, and Well-Being. Gastroenterology Nursing. 21(3),pp 112-118.

Tabibian, A., Tabibian, J.H., Beckman, L. J., Raffals, L. L., Papadakis, K.A., Kane, S.V., (2015). Predictors of Health-Related Quality of Life and Adherence in Crohn's Disease and Ulcerative Colitis: Implications for Clinical Management. Dig Dis Sci.60, pp1366-1374.

Taft, T. H., Keefer, L., Leonhard, C., Nealon-Woods, M. (2009). Impact of perceived stigma on inflammatory bowel disease patient outcomes. Inflammatory Bowel Diseases 15(8), pp 1224-1232.

Timmer, A., Preiss, J. C., Motschall, E., Rücker G., Jantschek G., Moser G. (2011). Psychological interventions for treatment of inflammatory bowel disease (Review). The Cochrane Library (8).

Triantafillidis, J.K., Merikas, E., Aristofanis G.(2013). Psychological factors and stress in inflammatory bowel disease. Expert Review of Gastroenterology \& Hepatology. 7(3), pp 225-238

Turnbull, G. K., Vallis, T.M., (1995). Quality of life in inflammatory bowel disease: The interaction of disease activity with psychosocial function. American Journal of Gastroenterology 90(9), pp 1450-1454.

Verissimo, R., Mota-Cardoso, R., Taylor, G., (1998). Relationships between alexithymia, emotional control, and duality of life in patients with inflammatory bowel disease.

Psychotherapy and Psychosomatics 67(2),pp 75-80.

Waters, E., Corcoran, D. \& Anafarta, M. (2005). Attachment, Other Relationships, and the Theory that All Good Things Go Together. Human Development 48, pp 80-84. 
Table 1. Studies included in systematic review.

\begin{tabular}{|c|c|c|c|c|c|c|c|}
\hline Reference & $\begin{array}{l}\text { Population } \\
\text { and location }\end{array}$ & $\begin{array}{l}\text { Recruitment and } \\
\text { response rates }\end{array}$ & $\begin{array}{l}\text { Study } \\
\text { design, }\end{array}$ & $\begin{array}{l}\text { Adjustment } \\
\text { measure }\end{array}$ & $\begin{array}{l}\text { Psychological } \\
\text { variable measure }\end{array}$ & Relevant findings & Total score \\
\hline $\begin{array}{l}\text { Boyle et al, } \\
2008\end{array}$ & $\begin{array}{l}\text { Norway and } \\
\text { Germany } \\
\text { N=109 (54 } \\
\text { UC, } 55 \text { CD) } \\
\text { 70\% female } \\
\text { Mean age: } \\
38.2\end{array}$ & $\begin{array}{l}\text { Multi centre } \\
\text { Selected sample } \\
\text { Eligibility criteria } \\
\text { specified. } \\
\text { Participation rate < } \\
75 \% \\
\text { Not adequately } \\
\text { powered }\end{array}$ & $\begin{array}{l}\text { Cross } \\
\text { sectional } \\
\text { Multiple } \\
\text { linear } \\
\text { regression } \\
\text { models. }\end{array}$ & $\begin{array}{l}\text { Quality of Ife: } \\
\text { SF-36 }\end{array}$ & $\begin{array}{l}\text { Aggression \& } \\
\text { hostility (BPA) } \\
\text { Neuroticism (EPQ) } \\
\text { Social desirability/ } \\
\text { conventionality } \\
\text { (EPQ-L) } \\
\text { Toronto Alexithymia } \\
\text { Scale (TAS) } \\
\text { Locus of } \\
\text { Control (MLOCS) }\end{array}$ & $\begin{array}{l}\text { Neuroticism, } \\
\text { powerful other locus } \\
\text { of control, chance } \\
\text { locus of control, } \\
\text { Agg/hostility (CD } \\
\text { only), age and clinical } \\
\text { activity associated } \\
\text { with reduced quality } \\
\text { of life. } \\
\text { Internal locus of } \\
\text { control associated } \\
\text { with better quality of } \\
\text { life. }\end{array}$ & $4 / 7$ \\
\hline $\begin{array}{l}\text { Crane et al, } \\
2004\end{array}$ & $\begin{array}{l}\text { UK } \\
N=33 \\
64 \% \text { female } \\
\text { Mean age: } \\
42\end{array}$ & $\begin{array}{l}\text { Single centre } \\
\text { Convenience } \\
\text { sample } \\
\text { Eligibility criteria } \\
\text { specified. } \\
\text { Participation rate < } \\
75 \% \\
\text { Not adequately } \\
\text { powered. }\end{array}$ & $\begin{array}{l}\text { Cross } \\
\text { sectional } \\
\text { Correlation }\end{array}$ & $\begin{array}{l}\text { Anxiety and } \\
\text { depression } \\
\text { (HADS) }\end{array}$ & Coping (VPMI) & $\begin{array}{l}\text { Emotion focused } \\
\text { coping associated } \\
\text { with depression. }\end{array}$ & $3 / 7$ \\
\hline $\begin{array}{l}\text { Caplan et } \\
\text { al, } 2014\end{array}$ & Canada & Single centre & $\begin{array}{l}\text { Cross } \\
\text { sectional }\end{array}$ & $\begin{array}{l}\text { Quality of life } \\
\text { (IBDQ) }\end{array}$ & $\begin{array}{l}\text { Attachment style } \\
\text { (ECR-R) }\end{array}$ & $\begin{array}{l}\text { Anxious attachment } \\
\text { associated with }\end{array}$ & $2 / 3$ \\
\hline
\end{tabular}




\begin{tabular}{|c|c|c|c|c|c|c|c|}
\hline & $\begin{array}{l}\mathrm{N}=193 \\
(62 \% \mathrm{UC}) \\
\\
56.6 \% \\
\text { female } \\
\\
\text { Mean age } \\
46.3\end{array}$ & $\begin{array}{l}\begin{array}{l}\text { Convenience } \\
\text { sample }\end{array} \\
\text { Eligibility criteria } \\
\text { not specified. } \\
\text { Participation rate< } \\
75 \% \\
\text { Not adequately } \\
\text { powered. }\end{array}$ & $\begin{array}{l}\text { Multiple } \\
\text { regression }\end{array}$ & & & $\begin{array}{l}\text { reduced quality of } \\
\text { life. }\end{array}$ & \\
\hline $\begin{array}{l}\text { Dorrian } \\
\text { et al, } 2009\end{array}$ & $\begin{array}{l}\text { Ireland \& } \\
\text { Scotland } \\
N=80 \\
54 \% \text { female } \\
\text { Mean age } \\
: 40 \\
\text { Mean } \\
\text { disease } \\
\text { duration: } \\
10.9 \text { years }\end{array}$ & $\begin{array}{l}\text { Single centre } \\
\text { Consecutive } \\
\text { sampling } \\
\text { Eligibility criteria } \\
\text { specified. } \\
\text { Participation rate < } \\
75 \% \\
\text { Adequately } \\
\text { powered. }\end{array}$ & $\begin{array}{l}\text { Cross } \\
\text { sectional } \\
\text { Hierarchical } \\
\text { regression } \\
\text { analyses }\end{array}$ & $\begin{array}{l}\text { Anxiety and } \\
\text { depression } \\
\text { (HADS) } \\
\text { Quality of life } \\
\text { (IBDQ) } \\
\text { Functional } \\
\text { Independence } \\
\text { (FLP) }\end{array}$ & $\begin{array}{l}\text { Illness Perceptions } \\
\text { (IPQ-R) }\end{array}$ & $\begin{array}{l}\text { Illness perceptions } \\
\text { (consequences), } \\
\text { emotion focused } \\
\text { coping strategies, } \\
\text { disease activity } \\
\text { associated with } \\
\text { reduced quality of } \\
\text { life. Coping did not } \\
\text { significantly add to } \\
\text { predicting } \\
\text { adjustment once } \\
\text { illness perceptions } \\
\text { were controlled for }\end{array}$ & $5 / 7$ \\
\hline $\begin{array}{l}\text { Faust et al, } \\
2012\end{array}$ & $\begin{array}{l}\text { USA. } \\
\mathrm{N}=80 \\
51 \% \text { female } \\
\text { Mean age: } \\
37.2\end{array}$ & $\begin{array}{l}\text { Single centre } \\
\text { Convenience } \\
\text { sample } \\
\text { Eligibility criteria } \\
\text { not specified. }\end{array}$ & $\begin{array}{l}\text { Cross } \\
\text { sectional } \\
\text { Hierarchical } \\
\text { regression }\end{array}$ & $\begin{array}{l}\text { Anxiety and } \\
\text { Depression } \\
\text { (HADS) } \\
\text { Quality of life } \\
\text { (SIBDQ). }\end{array}$ & $\begin{array}{l}\text { Coping (COPE } \\
\text { questionnaire) } \\
\text { Social Constraint } \\
\text { Questionnaire (SCQ) }\end{array}$ & $\begin{array}{l}\text { No association } \\
\text { between coping and } \\
\text { anxiety, depression, } \\
\text { reduced quality of } \\
\text { life. } \\
\text { Social constraint } \\
\text { associated with }\end{array}$ & $2 / 7$ \\
\hline
\end{tabular}




\begin{tabular}{|c|c|c|c|c|c|c|c|}
\hline & & $\begin{array}{l}\text { Participation rate < } \\
75 \% \\
\text { Not Adequately } \\
\text { powered }\end{array}$ & & & & $\begin{array}{l}\text { reduced quality of } \\
\text { life. }\end{array}$ & \\
\hline $\begin{array}{l}\text { Flett et al, } \\
2011 .\end{array}$ & $\begin{array}{l}\text { Canada } \\
N=51 \\
(27 C D 24 \\
\text { UC) } \\
61 \% \text { female } \\
\text { mean age: } \\
37.7 \\
\text { disease } \\
\text { duration: } \\
9.29 \text { years }\end{array}$ & $\begin{array}{l}\text { Multi centre } \\
\text { Convenience } \\
\text { sample } \\
\text { Eligibility criteria } \\
\text { specified. } \\
\text { Participation rate> } \\
75 \% \\
\text { Not adequately } \\
\text { powered. }\end{array}$ & $\begin{array}{l}\text { Cross } \\
\text { sectional } \\
\text { Bivariate } \\
\text { correlation }\end{array}$ & $\begin{array}{l}\text { The } \\
\text { Psychosocial } \\
\text { Impact } \\
\text { subscale of the } \\
\text { Sickness } \\
\text { Impact Profile } \\
\text { (SIP136) }\end{array}$ & $\begin{array}{l}\text { Perfectionism (MPS) } \\
\text { (PSPS) } \\
\text { Neuroticism (NEO- } \\
\text { PI-R) }\end{array}$ & $\begin{array}{l}\text { Perfectionism and } \\
\text { neuroticism } \\
\text { associated with } \\
\text { reduced quality of } \\
\text { life. }\end{array}$ & $5 / 7$ \\
\hline $\begin{array}{l}\text { Goodhand } \\
\text { et al, } 2012\end{array}$ & $\begin{array}{l}\text { London UK. } \\
N=204 \\
U / C=103 \\
49 \% \text { female } \\
\text { Mean age } \\
: 42) \\
C D=101 \\
57 \% \text { female } \\
\text { Mean age: } \\
43\end{array}$ & $\begin{array}{l}\text { Single centre } \\
\text { Selected sample } \\
\text { Eligibility criteria } \\
\text { specified. } \\
\text { Participation rate < } \\
75 \% \\
\text { Not adequately } \\
\text { powered. }\end{array}$ & $\begin{array}{l}\text { Cross } \\
\text { sectional } \\
\text { two-step } \\
\text { Multiple } \\
\text { linear } \\
\text { regression } \\
\text { models }\end{array}$ & $\begin{array}{l}\text { Anxiety and } \\
\text { depression } \\
\text { (HADS) }\end{array}$ & $\begin{array}{l}\text { General Perceived } \\
\text { Stress Questionnaire } \\
\text { (G-PSQ) }\end{array}$ & $\begin{array}{l}\text { In UC, anxiety scores } \\
\text { were associated with } \\
\text { perceived stress } \\
\text { and a new diagnosis } \\
\text { of IBD; depression } \\
\text { was associated with } \\
\text { stress, inpatient } \\
\text { status, and active } \\
\text { disease. In CD, } \\
\text { anxiety was } \\
\text { associated with per- } \\
\text { ceived stress, } \\
\text { abdominal pain, and } \\
\text { lower socioeconomic } \\
\text { status, and } \\
\text { depression with }\end{array}$ & $3 / 7$ \\
\hline
\end{tabular}




\begin{tabular}{|c|c|c|c|c|c|c|c|}
\hline & & & & & & $\begin{array}{l}\text { perceived stress and } \\
\text { increasing age. }\end{array}$ & \\
\hline $\begin{array}{l}\text { Iglesias-rey } \\
\text { et al } 2012\end{array}$ & $\begin{array}{l}\text { Spain } \\
N=484 \\
U C=292 \\
49 \% \text { female } \\
\text { Mean age: } \\
47 \\
C D=192 \\
\text { female 58\%. } \\
\text { Mean age: } \\
38\end{array}$ & $\begin{array}{l}\text { Single centre } \\
\text { Convenience } \\
\text { sample. } \\
\text { Eligibility criteria } \\
\text { specified. } \\
\text { Participation rate< } \\
75 \% \\
\text { Not adequately } \\
\text { powered. }\end{array}$ & $\begin{array}{l}\text { Cross } \\
\text { sectional } \\
\text { Multiple } \\
\text { linear } \\
\text { regression } \\
\text { and logistic } \\
\text { regression }\end{array}$ & $\begin{array}{l}\text { Anxiety and } \\
\text { depression } \\
\text { (HADS) } \\
\text { Quality of life } \\
\text { (IBDQ) ( SF- } \\
\text { 36) }\end{array}$ & $\begin{array}{l}\text { Alexithymia scale } \\
\text { (TAS-26) }\end{array}$ & $\begin{array}{l}\text { Alexithymia, age and } \\
\text { disease activity } \\
\text { associated with } \\
\text { reduced quality of } \\
\text { life. }\end{array}$ & $4 / 7$ \\
\hline $\begin{array}{l}\text { Kiebles et } \\
\text { al, } 2010\end{array}$ & $\begin{array}{l}\text { USA } \\
\mathrm{N}=38 \\
63 \% \\
\text { women } \\
\text { Mean age: } \\
36.2 \\
\text { Disease } \\
\text { duration: } \\
10 \text { years }\end{array}$ & $\begin{array}{l}\text { Single centre } \\
\text { Convenience } \\
\text { sample. } \\
\text { Eligibility criteria } \\
\text { specified. } \\
\text { Participation rate< } \\
75 \% \\
\text { Not adequately } \\
\text { powered. }\end{array}$ & $\begin{array}{l}\text { Cross } \\
\text { sectional } \\
\text { Pearson's } \\
\text { product } \\
\text { moment } \\
\text { correlation } \\
\text { coefficient }\end{array}$ & $\begin{array}{l}\text { Quality of life } \\
\text { : IBDQ } \\
\text { Emotional } \\
\text { distress( BSI) }\end{array}$ & $\begin{array}{l}\text { Coping( BRIEF COPE) } \\
\text { Perceived Stress } \\
\text { (PSQ) } \\
\text { Illness Perceptions } \\
\text { (IPQ-R) } \\
\text { Acceptance (DDAQ) }\end{array}$ & $\begin{array}{l}\text { Emotion focused } \\
\text { coping associated } \\
\text { with reduced quality } \\
\text { of life. Symptom } \\
\text { tolerance, activity } \\
\text { engagement } \\
\text { associated with } \\
\text { better quality of life. }\end{array}$ & $3 / 7$ \\
\hline $\begin{array}{l}\text { Kinash et } \\
\text { al, } 1993\end{array}$ & $\begin{array}{l}\text { Canada } \\
\mathrm{N}=150\end{array}$ & $\begin{array}{l}\text { Single centre } \\
\text { Convenience } \\
\text { sample }\end{array}$ & $\begin{array}{l}\text { Cross } \\
\text { sectional } \\
\text { Bivariate } \\
\text { correlation }\end{array}$ & $\begin{array}{l}\text { Depression } \\
\text { (BDI) }\end{array}$ & Coping (JCS) & $\begin{array}{l}\text { Emotion focused } \\
\text { coping associated } \\
\text { with depression. }\end{array}$ & $4 / 7$ \\
\hline
\end{tabular}




\begin{tabular}{|c|c|c|c|c|c|c|c|}
\hline & $\begin{array}{l}(88 \text { UC } 62 \\
C D) \\
48 \% \text { female } \\
62 \% \text { aged } \\
25-44\end{array}$ & $\begin{array}{l}\text { Eligibility criteria } \\
\text { specified. } \\
\text { Participation rate> } \\
75 \% \\
\text { Not adequately } \\
\text { powered. }\end{array}$ & & & & & \\
\hline $\begin{array}{l}\text { Lui et al, } \\
2013\end{array}$ & $\begin{array}{l}\text { China } \\
N=80 \mathrm{CD} \\
25 \% \text { female }\end{array}$ & $\begin{array}{l}\text { Single Centre } \\
\text { Convenience } \\
\text { sample } \\
\text { Eligibility criteria } \\
\text { specified. } \\
\text { Participation rate< } \\
75 \% \\
\text { Not adequately } \\
\text { powered. }\end{array}$ & $\begin{array}{l}\text { Cross } \\
\text { sectional } \\
\text { Multiple } \\
\text { linear } \\
\text { regression } \\
\text { analysis }\end{array}$ & $\begin{array}{l}\text { Quality of life } \\
\text { IBDQ) }\end{array}$ & Neuroticism (EPI) & $\begin{array}{l}\text { Neuroticism } \\
\text { associated with } \\
\text { reduced quality of } \\
\text { life. }\end{array}$ & $3 / 7$ \\
\hline $\begin{array}{l}\text { Maunder } \\
\text { et al, } 2005\end{array}$ & $\begin{array}{l}\text { Canada } \\
\text { T1 N=146 } \\
\text { (44.5\% } \\
\text { female, } \\
\text { Mean age } \\
\text { 42, Mean } \\
\text { Disease } \\
\text { duration } \\
14.6 \text { years) } \\
\text { T2 N=99 }\end{array}$ & $\begin{array}{l}\text { Single centre } \\
\text { Convenience } \\
\text { sample } \\
\text { Eligibility criteria } \\
\text { specified. } \\
\text { Participation rate< } \\
75 \% \\
\text { Not adequately } \\
\text { powered. }\end{array}$ & $\begin{array}{l}\text { Longitudinal } \\
\text { correlation }\end{array}$ & $\begin{array}{l}\text { Depression } \\
\text { (CES-D) }\end{array}$ & $\begin{array}{l}\text { Attachment style } \\
\text { (ECR-R) }\end{array}$ & $\begin{array}{l}\text { Avoidant } \\
\text { attachment, anxious } \\
\text { attachment } \\
\text { associated with } \\
\text { depression. }\end{array}$ & $3 / 7$ \\
\hline
\end{tabular}




\begin{tabular}{|c|c|c|c|c|c|c|c|}
\hline & $\begin{array}{l}(45.4 \% \\
\text { female, } \\
\text { Mean age } 45 \\
\text { Mean } \\
\text { Disease } \\
\text { duration } \\
16.4 \text { years) }\end{array}$ & & & & & & \\
\hline $\begin{array}{l}\text { Moreno- } \\
\text { Jimenez et } \\
\text { al, } 2007\end{array}$ & $\begin{array}{l}\text { SPAIN } \\
\mathrm{N}=120 \\
\text { Female } 47 \% \\
\text { Mean age } 43 \\
\text { Disease } \\
\text { duration: } \\
8.48 \text { years. }\end{array}$ & $\begin{array}{l}\text { Single centre } \\
\text { Convenience } \\
\text { sample }\end{array}$ & $\begin{array}{l}\text { Cross } \\
\text { sectional } \\
\text { Hierarchical } \\
\text { regression } \\
\text { analyses }\end{array}$ & $\begin{array}{l}\text { Quality of life } \\
\text { (IBDQ) }\end{array}$ & $\begin{array}{l}\text { Self-esteem (RSE) } \\
\text { Neuroticism } \\
\text { (EPI) }\end{array}$ & $\begin{array}{l}\text { Neuroticism, female, } \\
\text { treatment, number } \\
\text { of relapses per year } \\
\text { associated with } \\
\text { reduced quality of } \\
\text { life. } \\
\text { Higher self- esteem } \\
\text { associated with } \\
\text { increased quality of } \\
\text { life. }\end{array}$ & $4 / 7$ \\
\hline $\begin{array}{l}\text { Munson et } \\
\text { al, } 2009 .\end{array}$ & $\begin{array}{l}\text { USA } \\
N=260 \\
6.2 \% \text { female } \\
\text { Mean age: } \\
63\end{array}$ & $\begin{array}{l}\text { Multi centre } \\
\text { Convenience } \\
\text { sample } \\
\text { Eligibility criteria } \\
\text { specified. } \\
\text { Participation rate< } \\
75 \% \\
\text { Not adequately } \\
\text { powered. }\end{array}$ & $\begin{array}{l}\text { Cross } \\
\text { sectional } \\
\text { Sequential } \\
\text { multivariate } \\
\text { linear } \\
\text { regression }\end{array}$ & $\begin{array}{l}\text { Quality of life } \\
\text { (SIBDQ) }\end{array}$ & $\begin{array}{l}\text { Skills, knowledge } \\
\text { confidence. } \\
\text { (PAM) (PEI) }\end{array}$ & $\begin{array}{l}\text { Increased skills and } \\
\text { confidence } \\
\text { associated with } \\
\text { increased quality of } \\
\text { life. }\end{array}$ & $4 / 7$ \\
\hline $\begin{array}{l}\text { Mussell et } \\
\text { al, } 2004\end{array}$ & $\begin{array}{l}\text { Germany } \\
N=72 \\
58 \% \text { female }\end{array}$ & $\begin{array}{l}\text { Single centre } \\
\text { Consecutive } \\
\text { sample }\end{array}$ & $\begin{array}{l}\text { Cross } \\
\text { sectional }\end{array}$ & $\begin{array}{l}\text { Quality of life } \\
\text { (RFIPC) }\end{array}$ & $\begin{array}{l}\text { Coping (FQ) } \\
\text { Illness and health } \\
\text { locus of control } \\
((\mathrm{MHLC})\end{array}$ & $\begin{array}{l}\text { Emotion focused } \\
\text { coping, female, } \\
\text { disease activity } \\
\text { associated with }\end{array}$ & $5 / 7$ \\
\hline
\end{tabular}




\begin{tabular}{|c|c|c|c|c|c|c|c|}
\hline & $\begin{array}{l}\text { Disease } \\
\text { duration: } \\
11.7 y r s\end{array}$ & $\begin{array}{l}\text { Eligibility criteria } \\
\text { specified. } \\
\text { Participation rate> } \\
75 \% \\
\text { Not adequately } \\
\text { powered. }\end{array}$ & $\begin{array}{l}\text { Multiple } \\
\text { regression } \\
\text { analysis }\end{array}$ & $\begin{array}{l}\text { Psychological } \\
\text { distress (SCL- } \\
90-R) \\
\text { Somatic } \\
\text { complaints } \\
\text { (FCL) }\end{array}$ & & $\begin{array}{l}\text { reduced quality of } \\
\text { life. } \\
\text { Locus of control not } \\
\text { associated with } \\
\text { quality of life. }\end{array}$ & \\
\hline $\begin{array}{l}\text { Olbrisch, et } \\
\text { al, } 1982\end{array}$ & $\begin{array}{l}\text { USA } \\
\mathrm{N}=143 \\
55 \% \text { female } \\
\text { Mean age } \\
: 39 \\
\text { Disease } \\
\text { duration: } 10 \\
\text { years. }\end{array}$ & $\begin{array}{l}\text { Single centre } \\
\text { Convenience } \\
\text { sample } \\
\text { Eligibility criteria } \\
\text { not specified. } \\
\text { Participation rate< } \\
75 \% \\
\text { Not adequately } \\
\text { powered. }\end{array}$ & $\begin{array}{l}\text { Cross } \\
\text { sectional } \\
\text { Multiple } \\
\text { regression }\end{array}$ & $\begin{array}{l}\text { Psychological } \\
\text { adjustment: } \\
\text { experience } \\
\text { scale }\end{array}$ & $\begin{array}{l}\text { Private self- } \\
\text { consciousness (SCS) }\end{array}$ & $\begin{array}{l}\text { Private self- } \\
\text { consciousness } \\
\text { associated with } \\
\text { psychological } \\
\text { distress. }\end{array}$ & $2 / 7$ \\
\hline $\begin{array}{l}\text { Petrak et } \\
\text { al, } 2001\end{array}$ & $\begin{array}{l}\text { Germany } \\
N=1322 \\
52 \% \text { female } \\
\text { Mean age } \\
39.6\end{array}$ & $\begin{array}{l}\text { Multicentre } \\
\text { Consecutive } \\
\text { sample } \\
\text { Eligibility criteria } \\
\text { specified. } \\
\text { Participation rate< } \\
75 \% \\
\text { Not adequately } \\
\text { powered. }\end{array}$ & $\begin{array}{l}\text { Cross } \\
\text { sectional } \\
\text { Multiple, } \\
\text { non-linear } \\
\text { regression } \\
\text { analysis }\end{array}$ & $\begin{array}{l}\text { Quality of life } \\
\text { :Sf-36 }\end{array}$ & $\begin{array}{l}\text { Coping (FKV-LIS) } \\
\text { Hopelessness (H- } \\
\text { RB-Skala) }\end{array}$ & $\begin{array}{l}\text { Emotion focused } \\
\text { coping, } \\
\text { hopelessness, older } \\
\text { age, disease activity, } \\
\text { associated with } \\
\text { reduced quality of } \\
\text { life. }\end{array}$ & $5 / 7$ \\
\hline
\end{tabular}




\begin{tabular}{|c|c|c|c|c|c|c|c|}
\hline $\begin{array}{l}\text { Sajadinejad } \\
\text { et al, } 2012\end{array}$ & $\begin{array}{l}\text { Iran } \\
N=58 \text { UC } \\
100 \% \text { female } \\
\text { Mean age } 35\end{array}$ & $\begin{array}{l}\text { Single centre } \\
\text { Convenience } \\
\text { sample } \\
\text { Eligibility criteria } \\
\text { specified. } \\
\text { Participation rate< } \\
75 \% \\
\text { Not adequately } \\
\text { powered. }\end{array}$ & $\begin{array}{l}\text { Cross } \\
\text { sectional } \\
\text { ANOVA test }\end{array}$ & $\begin{array}{l}\text { Quality of life } \\
\text { : WHO Quality } \\
\text { of Life } \\
\text { questionnaire }\end{array}$ & $\begin{array}{l}\text { Type D personality } \\
\text { (DS14), neuroticism } \\
\text { (NEO-FFI) }\end{array}$ & $\begin{array}{l}\text { Type D personality, } \\
\text { neuroticism } \\
\text { associated with } \\
\text { reduced quality of } \\
\text { life. }\end{array}$ & $3 / 7$ \\
\hline $\begin{array}{l}\text { Seres et al } \\
2008 .\end{array}$ & $\begin{array}{l}\text { Hungary } \\
\mathrm{N}=66 \text { UC } \\
70 \% \text { female }\end{array}$ & $\begin{array}{l}\text { Single centre } \\
\text { Convenience } \\
\text { sample } \\
\text { Eligibility criteria } \\
\text { specified. } \\
\text { Participation rate> } \\
75 \% \\
\text { Not adequately } \\
\text { powered. }\end{array}$ & $\begin{array}{l}\text { Cross } \\
\text { sectional } \\
\text { Analysis of } \\
\text { covariance }\end{array}$ & $\begin{array}{l}\text { Quality of life: } \\
\text { Irritable Bowel } \\
\text { Syndrome } \\
\text { Quality of Life } \\
\text { Questionnaire } \\
\text { (IBSQOL) }\end{array}$ & Coping (CSO) & $\begin{array}{l}\text { Emotion focused } \\
\text { coping associated } \\
\text { with reduced quality } \\
\text { of life. }\end{array}$ & $4 / 7$ \\
\hline $\begin{array}{l}\text { Sewitch et } \\
\text { al, } 2001\end{array}$ & $\begin{array}{l}\text { Canada } \\
\mathrm{N}=200\end{array}$ & $\begin{array}{l}\text { Single centre } \\
\text { Convenience } \\
\text { sample }\end{array}$ & $\begin{array}{l}\text { Cross } \\
\text { sectional } \\
\text { Multiple }\end{array}$ & $\begin{array}{l}\text { Psychological } \\
\text { distress } \\
\text { (Symptom } \\
\text { Checklist-90R) }\end{array}$ & $\begin{array}{l}\text { Perceptions of stress } \\
\text { (PSQ) } \\
\text { Perceptions of social } \\
\text { support (SSQ-6) }\end{array}$ & $\begin{array}{l}\text { Perceptions of stress, } \\
\text { active disease, less } \\
\text { time since diagnosis } \\
\text { associated with }\end{array}$ & $4 / 7$ \\
\hline
\end{tabular}




\begin{tabular}{|c|c|c|c|c|c|c|c|}
\hline & $\begin{array}{l}\text { (167 CD, } 37 \\
\text { UC) } \\
60 \% \text { female } \\
\text { Mean age } \\
: 38 \\
\text { Mean } \\
\text { Disease } \\
\text { duration: } 8.1 \\
\text { years }\end{array}$ & $\begin{array}{l}\text { Eligibility criteria } \\
\text { specified. } \\
\text { Participation rate> } \\
75 \% \\
\text { Not adequately } \\
\text { powered. }\end{array}$ & $\begin{array}{l}\text { linear } \\
\text { regression }\end{array}$ & & & $\begin{array}{l}\text { increased } \\
\text { psychological } \\
\text { distress. } \\
\text { High satisfaction with } \\
\text { social support } \\
\text { mitigates impact of } \\
\text { stress on adjustment } \\
\text { outcomes. }\end{array}$ & \\
\hline $\begin{array}{l}\text { Smolen et } \\
\text { al, } 1993 .\end{array}$ & $\begin{array}{l}\text { USA } \\
N=46(33 \\
C D, 13 \cup C) \\
74 \% \text { female } \\
\text { Mean age: } \\
44.2\end{array}$ & $\begin{array}{l}\text { Single centre } \\
\text { Convenience } \\
\text { sample } \\
\text { Eligibility criteria } \\
\text { specified. } \\
\text { Participation rate> } \\
75 \% \\
\text { Not adequately } \\
\text { powered. }\end{array}$ & $\begin{array}{l}\text { Cross } \\
\text { sectional } \\
\text { Stepwise } \\
\text { regression } \\
\text { analysis }\end{array}$ & $\begin{array}{l}\text { Quality of life } \\
: \text { Medical } \\
\text { Outcome Study } \\
\text { Short-Form } \\
\text { Health survey } \\
\text { (SF-36) }\end{array}$ & Coping (JCS) & $\begin{array}{l}\text { Emotion focused } \\
\text { coping associated } \\
\text { with reduced quality } \\
\text { of life. } \\
\text { Optimistic coping } \\
\text { associated with } \\
\text { increased quality of } \\
\text { life. }\end{array}$ & $4 / 7$ \\
\hline $\begin{array}{l}\text { Tabibian et } \\
\text { al, } 2015\end{array}$ & $\begin{array}{l}\text { USA } \\
\mathrm{N}=136 \\
(57 \% \mathrm{CD}, \\
43 \% \mathrm{UC}) \\
82 \% \text { female } \\
\text { Mean age: } \\
32.5\end{array}$ & $\begin{array}{l}\text { Single centre } \\
\text { Convenience } \\
\text { sample } \\
\text { Eligibility criteria } \\
\text { specified. } \\
\text { Participation rate< } \\
75 \%\end{array}$ & $\begin{array}{l}\text { Cross } \\
\text { sectional } \\
\text { Multivariate } \\
\text { linear } \\
\text { regression }\end{array}$ & $\begin{array}{l}\text { Quality of life } \\
\text { (IBDQ) }\end{array}$ & $\begin{array}{l}\text { Perceived Stress } \\
\text { Scale (PSS-10) }\end{array}$ & $\begin{array}{l}\text { Perceived stress, } \\
\text { number of relapses } \\
\text { per year, female, } \\
\text { being older } \\
\text { associated with } \\
\text { reduced quality of } \\
\text { life. }\end{array}$ & $3 / 7$ \\
\hline
\end{tabular}




\begin{tabular}{|c|c|c|c|c|c|c|c|}
\hline & & $\begin{array}{l}\text { Not adequately } \\
\text { powered. }\end{array}$ & & & & & \\
\hline Taft et al, & $\begin{array}{l}\text { USA } \\
N=211 \\
(156 \mathrm{CD}, 55 \\
\text { UC) } \\
77 \% \text { female } \\
69 \% \text { were } \\
\text { under age } \\
46 \\
\\
43 \% \\
\text { diagnosed } \\
\text { within the } \\
\text { last } 5 \text { years }\end{array}$ & $\begin{array}{l}\text { Multicentre } \\
\text { Convenience } \\
\text { sample } \\
\text { Eligibility criteria } \\
\text { not specified. } \\
\text { Participation rate< } \\
75 \% \\
\text { Not adequately } \\
\text { powered. }\end{array}$ & $\begin{array}{l}\text { Cross } \\
\text { sectional } \\
\text { Hierarchical } \\
\text { regression } \\
\text { analyses }\end{array}$ & $\begin{array}{l}\text { Psychological } \\
\text { distress( BSI- } \\
\text { 18) } \\
\text { Quality of life } \\
\text { (IBDQ) }\end{array}$ & $\begin{array}{l}\text { Perceived Stigma } \\
\text { (PSS-IBS) }\end{array}$ & $\begin{array}{l}\text { Perceived stigma } \\
\text { associated with } \\
\text { increased } \\
\text { psychological } \\
\text { distress and reduced } \\
\text { quality of life. }\end{array}$ & $3 / 7$ \\
\hline $\begin{array}{l}\text { Turnball et } \\
\text { al, } 1995 .\end{array}$ & $\begin{array}{l}\text { Canada } \\
\mathrm{N}=22(16 \mathrm{CD} \\
6 \mathrm{UC}) \\
64 \% \text { female } \\
\text { Mean age: } \\
32 \\
\begin{array}{l}\text { Mean age of } \\
\text { onset: } 26 \\
\text { years }\end{array}\end{array}$ & $\begin{array}{l}\text { Single centre. } \\
\text { Consecutive } \\
\text { sample. } \\
\text { Eligibility criteria } \\
\text { specified. } \\
\text { Participation rate< } \\
75 \% \\
\text { Not adequately } \\
\text { powered. }\end{array}$ & $\begin{array}{l}\text { Cross } \\
\text { sectional } \\
\text { Regression } \\
\text { analysis }\end{array}$ & $\begin{array}{l}\text { Sickness } \\
\text { Impact Profile } \\
\text { (SIP) } \\
\text { The Symptom } \\
\text { Checklist-90-R } \\
\text { (SCL) } \\
\text { Quality of life } \\
\text { (IBDQ) }\end{array}$ & Coping (SCS) & $\begin{array}{l}\text { Coping, disease type, } \\
\text { gender, age of onset } \\
\text { not associated with } \\
\text { quality of life. }\end{array}$ & $4 / 7$ \\
\hline $\begin{array}{l}\text { Verissimo } \\
\text { et al, } 1998\end{array}$ & $\begin{array}{l}\text { Portugal } \\
N=74\end{array}$ & Single centre & $\begin{array}{l}\text { Cross } \\
\text { sectional }\end{array}$ & $\begin{array}{l}\text { Quality of life } \\
\text { (IBDQ) }\end{array}$ & Alexithymia (TAS) & $\begin{array}{l}\text { Alexithymia, } \\
\text { education, } \\
\text { socioeconomic index }\end{array}$ & $3 / 7$ \\
\hline
\end{tabular}




\begin{tabular}{|c|c|c|c|c|}
\hline $\begin{array}{l}65 \% \text { female } \\
\text { Mean } \\
\text { age: } 38.1 \\
\text { Disease } \\
\text { duration: } 10 \\
\text { years }\end{array}$ & 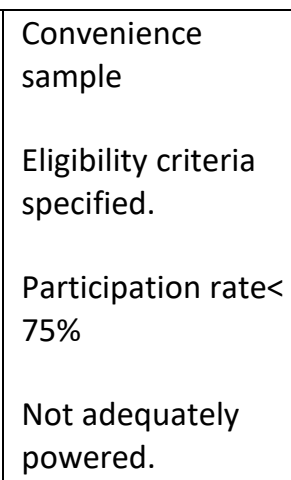 & $\begin{array}{l}\text { Hierarchical, } \\
\text { stepwise } \\
\text { multiple } \\
\text { regression } \\
\text { analysis }\end{array}$ & $\begin{array}{l}\text { The Emotional } \\
\text { Expression and } \\
\text { Control (EEC) }\end{array}$ & $\begin{array}{l}\text { associated with } \\
\text { reduced quality of } \\
\text { life. } \\
\text { Higher emotional } \\
\text { control associated } \\
\text { with increased } \\
\text { quality of life. }\end{array}$ \\
\hline
\end{tabular}


Table 2. Identified psychological variables.

\begin{tabular}{|l|l|l|l|}
\hline Category & Variable & $\begin{array}{l}\text { No of studies examining } \\
\text { the variable }\end{array}$ & Total sample size \\
\hline Personality traits & neuroticism & 5 & 418 \\
\hline & Type D & 1 & 58 \\
\hline & Perfectionism & 1 & 51 \\
\hline Interpersonal traits & Attachment & 2 & 339 \\
\hline Stress and coping & Stress & 4 & 578 \\
\hline & Coping & 10 & 1909 \\
\hline $\begin{array}{l}\text { Emotions and emotional } \\
\text { control }\end{array}$ & Alexithymia & 4 & 787 \\
\hline & & & \\
\hline & Aggression \& hostility & 2 & 189 \\
\hline & Private self -consciousness & 1 & 143 \\
\hline IBD related cognitions & Active restraint of emotions & 1 & 74 \\
\hline & Locus of control & 2 & 181 \\
\hline & Stigma & 1 & 211 \\
\hline & & & \\
\hline & Social constraint & 1 & 80 \\
\hline & Illness perceptions & 2 & 118 \\
\hline & Acceptance & 1 & 38 \\
\hline Non IBD related cognitions & Adaptive capacities & 1 & 260 \\
\hline & Self esteem & 1 & 120 \\
\hline & General hopelessness & 1 & 1322 \\
\hline
\end{tabular}


Fig. 1 Flow chart of the selection of relevant studies.

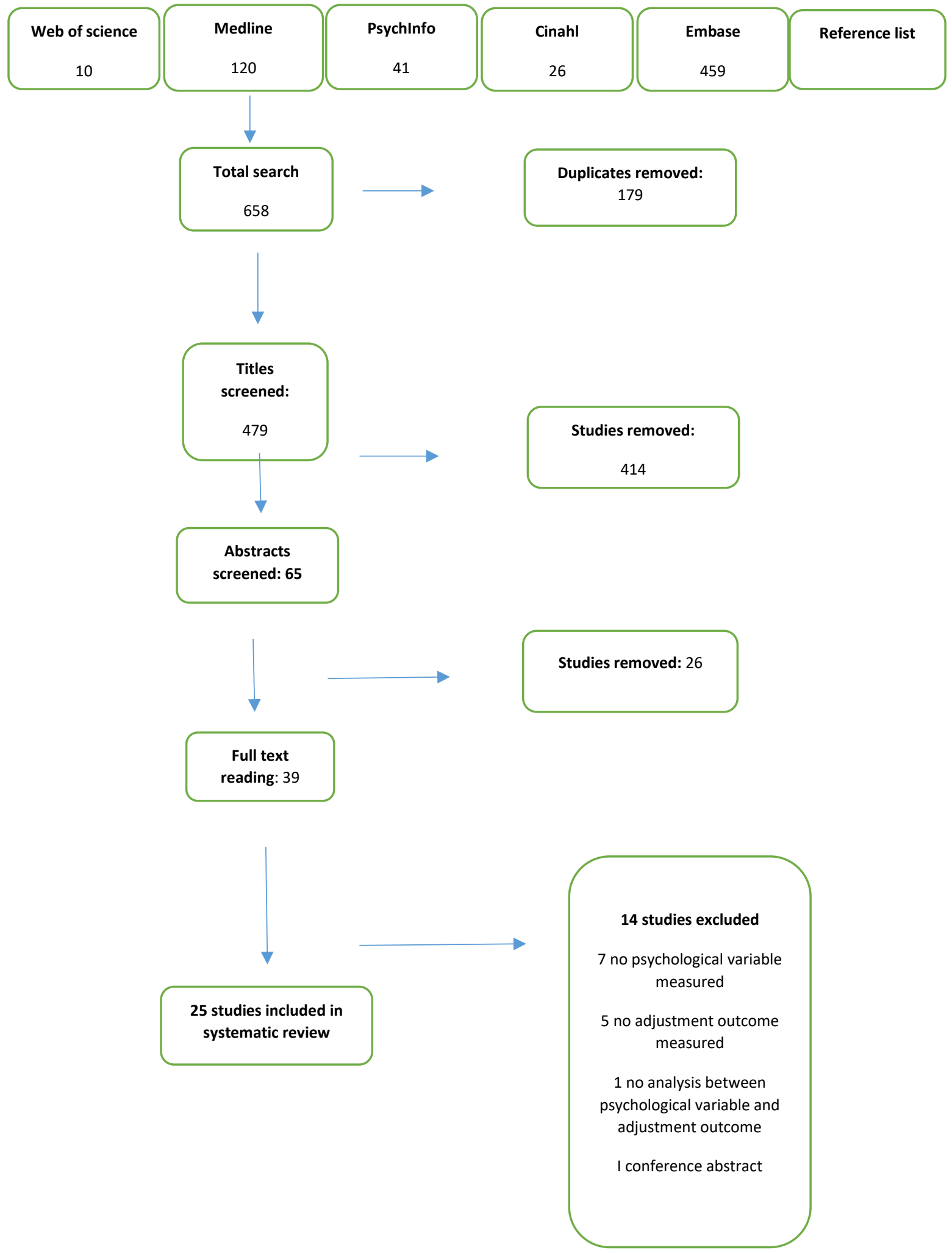


Figure 2: Model of psychological factors linked to adjustment in IBD.

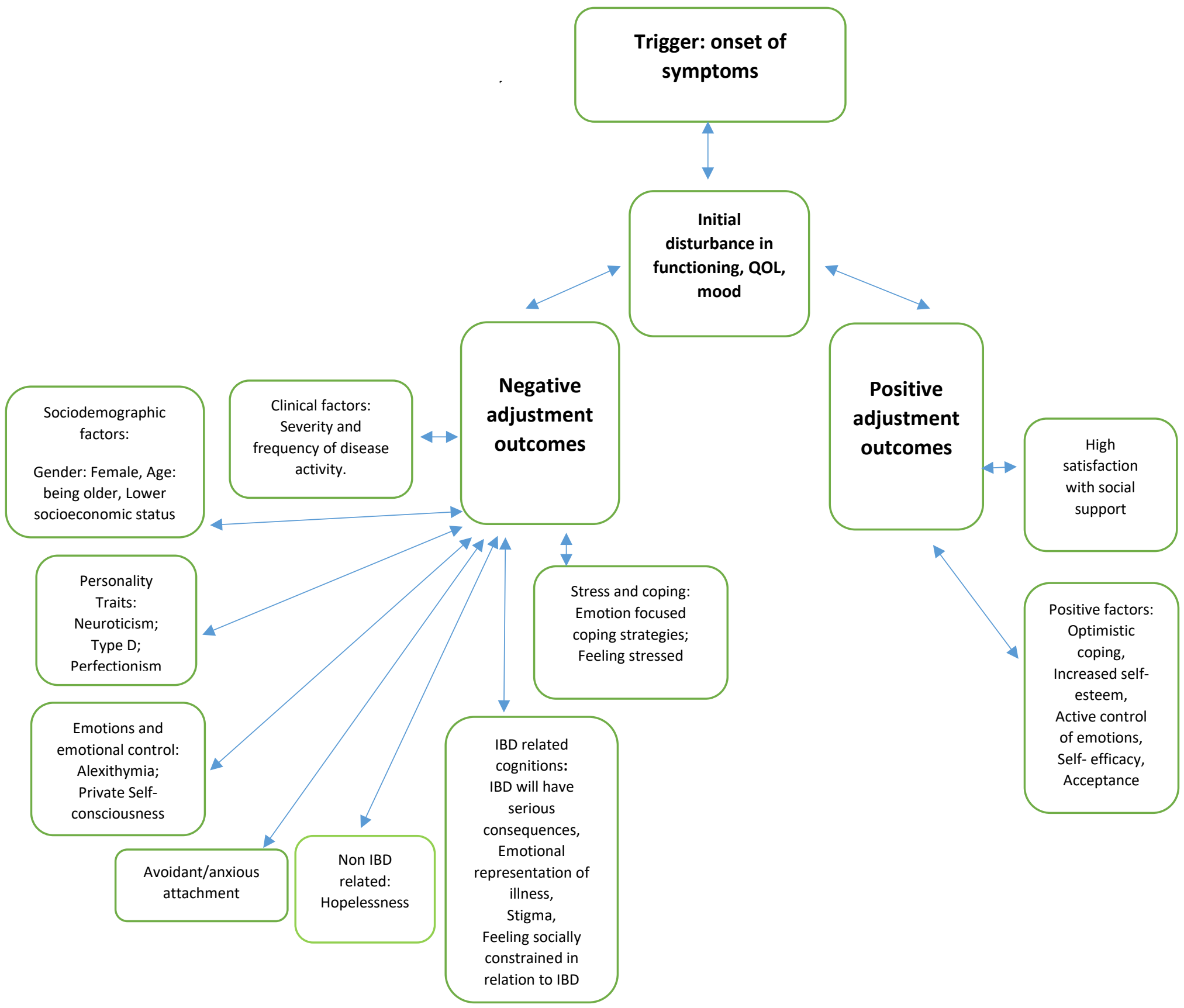




\section{Appendix One:}

\section{The Psychosocial factors associated with adjustment in Inflammatory bowel disease.}

\section{Search Terms}

Inflammatory bowel disease or IBD or Crohn disease or CD or Ulcerative colitis or UC

AND

Adults

The search above was completed in combination with the following psychosocial factors:

Psychological adjustment

Psychological factors

Psychological distress

Emotional adjustment

Stress

Alexithymia

Depression

Anxiety

Mood

Personality traits

perfectionism

neuroticism

illness perceptions

illness cognitions

illness related attitudes

illness behaviour

coping strategies

coping behaviour

stigmatisation

Attributions

Quality of life 
etiology

social support

demographic factors

Gender

age

educational level

Determin\$

Predict\$

Correlate\$

Cohort study

prospective study

observational study

Electronic databases searched:

Medline, Embase, Web of science, Cinahl and PsychINFO 